\title{
Carbon isotope discrimination and the factors affecting it in a summer maize field under different tillage systems
}

\author{
Jichao Cui ${ }^{1}$, Huifang Han ${ }^{\text {Corresp. } 1}$ \\ ${ }^{1}$ State Key Laboratory of Crop Biology, Key Laboratory of Crop Water Physiology and Drought Tolerance Germplasm Improvement of Ministry of \\ Agriculture, Shandong Agricultural University, Tai'an, P.R. China, Tai'an, China \\ Corresponding Author: Huifang Han \\ Email address: hhf@sdau.edu.cn
}

Based on two years of field experiments, under different soil tillage methods and straw management practices, which included conventional tillage (CT), subsoiling (SS), rotary tillage (RT), and no-tillage (NT), combined with either straw return (S) or straw removal $(0)$, we characterized the dynamic changes in $\Delta^{13} \mathrm{C}$ among three height layers [upper (U, 240 $\mathrm{cm}$ above the ground), middle (M, $120 \mathrm{~cm}$ above the ground), and lower $(\mathrm{L}, 30 \mathrm{~cm}$ above the ground)] of the summer maize canopy. The $\Delta{ }^{13} \mathrm{C}$, the factors affecting it, and the relationships between $\Delta^{13} \mathrm{C}$ and soil water content (SWC), the leaf area index (LAI), canopy microclimate, and the $\mathrm{CO}_{2}$ concentration were elucidated. The results indicated that the $\Delta^{13} \mathrm{C}$ of summer maize at the pre-filling stage was greater than that at the post-filling stage. $\Delta^{13} \mathrm{C}$ also varied at different heights, with the order of the $\Delta^{13} \mathrm{C}$ values being $\mathrm{L}>\mathrm{U}>$ $M$. Among the different tillage methods, the $\Delta^{13} \mathrm{C}$ values were ordered $\mathrm{SS}_{\mathrm{S}}>\mathrm{CT}_{\mathrm{S}}>\mathrm{RT}_{\mathrm{S}}>$ $\mathrm{NT}_{\mathrm{S}} . \mathrm{SS}_{\mathrm{S}}$ and $\mathrm{NT}_{\mathrm{S}}$ significantly increased the LAl; air temperature and relative humidity tended to gradually decrease with the increase in height of summer maize. Correlation analyses of the various influencing factors and $\Delta^{13} \mathrm{C}$ showed that SWC, LAI, air temperature, and $\mathrm{CO}_{2}$ concentration were all positively correlated with $\Delta^{13} \mathrm{C}$, in which LAI and air temperature were significantly or extremely significantly positively correlated with $\Delta \Delta^{13} \mathrm{C}$. In addition, we show that $\Delta^{13} \mathrm{C}$ can be used as a prediction index for summer maize yield, providing a theoretical basis for future yield research that may save precious time in summer maize breeding efforts. 
1 Carbon isotope discrimination and the factors affecting it in a summer maize

\section{field under different tillage systems}

3 Jichao Cui, Huifang Han *

4 State Key Laboratory of Crop Biology, Key Laboratory of Crop Water Physiology and Drought Tolerance

5 Germplasm Improvement of Ministry of Agriculture, Shandong Agricultural University, Tai'an, P.R. China

6 *Corresponding author: Huifang Han $\underline{\text { (hhf(s,sdau.edu.cn) }}$

\section{Abstract}

Based on two years of field experiments, under different soil tillage methods and straw management practices, which included conventional tillage (CT), subsoiling (SS), rotary tillage (RT), and no-tillage (NT), combined with either straw return(S) or straw removal (0), we characterized the dynamic changes in $\Delta^{13} \mathrm{C}$ among three height layers [upper (U, $240 \mathrm{~cm}$ above the ground), middle (M, $120 \mathrm{~cm}$ above the ground), and lower (L, $30 \mathrm{~cm}$ above the ground)] of the summer maize canopy. The $\Delta^{13} \mathrm{C}$, the factors affecting it, and the relationships between $\Delta{ }^{13} \mathrm{C}$ and soil water content (SWC), the leaf area index (LAI), canopy microclimate, and the $\mathrm{CO}_{2}$ concentration were elucidated. The results indicated that the $\Delta^{13} \mathrm{C}$ of summer maize at the pre-filling stage was greater than that at the post-filling stage. $\Delta^{13} \mathrm{C}$ also varied at different heights, with the order of the $\Delta^{13} \mathrm{C}$ values being $\mathrm{L}>\mathrm{U}>\mathrm{M}$. Among the different tillage methods, the $\Delta^{13} \mathrm{C}$ values were ordered $\mathrm{SS}_{\mathrm{S}}>\mathrm{CT}_{\mathrm{S}}>\mathrm{RT}_{\mathrm{S}}>\mathrm{NT}_{\mathrm{S}}$. $\mathrm{SS}_{\mathrm{S}}$ and $\mathrm{NT}_{\mathrm{S}}$ significantly increased the LAI; air temperature and relative humidity tended to gradually decrease with the increase in height of summer maize. Correlation analyses of the various influencing factors and $\Delta^{13} \mathrm{C}$ showed that SWC, LAI, air temperature, and $\mathrm{CO}_{2}$ concentration were all positively correlated with $\Delta^{13} \mathrm{C}$, in 
21 addition, we show that $\Delta^{13} \mathrm{C}$ can be used as a prediction index for summer maize yield, providing a theoretical

22 basis for future yield research that may save precious time in summer maize breeding efforts.

23 Keywords: Tillage methods; Soil water content; Leaf area index; Canopy temperature; Canopy

24 humidity

25

26

27

\section{Introduction}

Grain production in the North China Plain (NCP) accounts for one-third of China's total grain production, which is crucial for ensuring national food security. Maize, which is widely planted in the NCP, is an economically important crop that is an important source of food, forage, and raw material for industrial ethanol production. Long-term use of traditional tillage as the main farming method in this area not only cause soil hardening and shallow plowing layers but also reduces soil water storage and moisture conservation capacity, resulting in adverse consequences for high and stable grain yield (Bissett et al., 2013; Wang et al., 2018). The sustainable development of agriculture in the NCP is adversely affected by the destruction of soil structure, which reduces water use efficiency and crop yield (Balwinder-Singh et al., 2011; Latifmanesh et al., 2018).

Therefore, it is vital to find a reasonable land use technique that facilitates the maintenance of soil fertility and the improvement of grain yield. Conservation tillage is one such new land use method that mainly involves lesstillage or no-tillage technology and straw return (Xue et al., 2019). A large number of studies have shown that subsoiling, no-tillage, and other conservation tillage measures improve soil structure, enhance resistance to soil erosion and drought, improve soil water storage and moisture conservation capacity, improve water use efficiency (WUE), and significantly increase grain yield (Jennings et al., 2012; Shao et al., 2016; Xu et al., 2019).

The quick and accurate evaluation of maize WUE and yield under different tillage methods has important theoretical and practical significance. 
42 Carbon isotopes are natural tracers that indicate changes in carbon processes in agroecosystems and are often

used to determine the WUE and yield of ecosystems (Cui et al., 2009; Zhang et al., 2017). Under different tillage

treatments, the photosynthetic carbon sequestration efficiency of summer maize is different due to the differences in plant growth status and the field canopy microenvironment. Stable carbon isotope technology is one of the most effective methods for studying the relationship between plants and the environment. Due to the differences in plant carboxylation efficiency and ${ }^{12} \mathrm{C}$ and ${ }^{13} \mathrm{C}$ migration rates in plants and the external environment, the stable carbon isotope ratios differ between plants under different circumstances, which can be used to study ecosystem $\mathrm{C}$ cycling and its relationship with the environment as well as to understand changes in ecosystem function. Therefore, it represents an important means of studying ecosystem function and dynamic change. Stable isotope technology can be used to integrate temporal and spatial understanding of ecological processes, indicating the existence of key processes and their long-term development (Damesin et al., 2003).

Researchers have applied stable carbon isotope techniques to study agroecosystems, such as to the study of the return of straw as an organic carbon source to cropland, soil effects, and crop photosynthetic carbon interception (Kristiansen et al., 2005; Tharayi et al., 2011; Liu et al., 2019a). Liu et al. (2019b) reported that the $\Delta^{13} \mathrm{C}$ values of wheat organs can be used to evaluate changes and differences in yield and WUE. However, less effort has been directed at understanding the relationship between $\Delta^{13} \mathrm{C}$ and its influencing factors in summer maize fields with different tillage methods. There are few reports on the effect of canopy microclimate on the carbon isotope changes under different tillage methods.

This study was specifically designed to test the hypothesis that subsoiling and straw return can increase the $\Delta^{13} \mathrm{C}$ of summer maize, and have a positive correlation between the $\Delta^{13} \mathrm{C}$ in the middle layer and yield. Moreover, the sensitivity of $\Delta^{13} \mathrm{C}$ to various influencing factors may be different among the different summer maize layers.

Peer] reviewing PDF | (2021:06:63005:2:0:NEW 9 Jan 2022) 
63 The objectives of this study were: 1) to measure the change in $\Delta^{13} \mathrm{C}$ among the different summer maize layers

64

under different tillage methods; 2) to explore the relationship between $\Delta^{13} \mathrm{C}$ among the different summer maize layers and its influencing factors. This research can provide a basis for supplementing the carbon sequestration mechanisms of crop plants and for assessing effective soil carbon control and management measures.

\section{Materials and methods}

\subsection{Experimental site}

The experiment was conducted in a continuous, long-term (14 years) conservation tillage experiment at the Experimental Station of Shandong Agricultural University $\left(117^{\circ} 09^{\prime} 13.79^{\prime \prime}-117^{\circ} 09^{\prime} 12.02^{\prime \prime} \mathrm{E}, 36^{\circ} 09^{\prime} 30.78\right.$ $\left.36^{\circ} 09^{\prime} 27.59^{\prime \prime} \mathrm{N}\right)$; our experiment was performed over two years (2016-2017). The experimental area has a typical temperate continental climate with sufficient light and four distinct seasons. The annual average temperature is $13.6^{\circ} \mathrm{C}$. The annual average number of hours of sunlight is $2462.3 \mathrm{~h}$, and the annual average rainfall is 786.3 $\mathrm{mm}$. This site has a climate that is typical for the NCP. The soil type tested was brown soil with a deep soil layer, and the groundwater level was below $5 \mathrm{~m}$. Climate data for 2016-2017 is shown in Fig. 1. The soil texture is $40 \%$ sand, $44 \%$ silt, and $16 \%$ clay. The major initial properties within the $0-20 \mathrm{~cm}$ soil layer were as follows: $\mathrm{pH}$ of $7.09,7.19 \mathrm{~g} \cdot \mathrm{kg}^{-1} \mathrm{SOC}, 1.3 \mathrm{~g} \cdot \mathrm{kg}^{-1}$ total $\mathrm{N}, 0.79 \mathrm{mg} \cdot \mathrm{kg}^{-1}$ available $\mathrm{P}$, and $41.32 \mathrm{mg} \cdot \mathrm{kg}^{-1}$ exchangeable $\mathrm{K}$.

\subsection{Experimental design}

A split-plot design experiment was arranged with three replicates. The plot size was $15 \mathrm{~m} \times 4 \mathrm{~m}$ for every replicate. The experiment was divided into the main plot factor: four tillage methods [no-tillage (NT), rotary tillage (RT), subsoiling (SS), and conventional tillage (CT)] and the subplot-factor: straw management [straw return $(\mathrm{S})$ and straw removal (0)].

The winter wheat-summer maize was the typical double cropping rotation system. The winter wheat variety 
84

85

86

87

88

89

90

91

92

93

94

95

96

97

98

99

100

101

102

103

104

'Jimai22' was sown in the middle of October each year and harvested in the middle of June the next year. The summer maize variety was 'Zhengdan958', which was sown in the middle and late June of each year and harvested in the first ten days of October. During the summer maize growth period, basal fertilizer was applied at a rate of $120 \mathrm{~kg} \mathrm{~N} \mathrm{ha}^{-1}, 120 \mathrm{~kg} \mathrm{P}_{2} \mathrm{O}_{5} \mathrm{ha}^{-1}$, and $100 \mathrm{~kg} \mathrm{~K}_{2} \mathrm{O} \mathrm{ha}^{-1}$ before sowing, and topdressing fertilizer were applied at a rate of $120 \mathrm{~kg} \mathrm{~N} \mathrm{ha}^{-1}$ at the large mouth stage.

The four tillage methods in this experiment were carried out only before winter wheat sowing, and summer maize was sowed with no-tillage iron stubble. After harvest, the wheat straw and maize straw from the two seasons were completely crushed $(3-5 \mathrm{~cm})$ and returned to the field. For the SS treatment, subsoiler $(Z \mathrm{~S}-180)$ was used; the soil was plowed for the CT treatment and a rotavator $(\mathrm{C} 250)$ was used for the RT. Winter wheat was grown using a machine (LXH-150). After the winter wheat was machine-harvested, the straw treatments were applied as described above, and summer maize was sown directly by machine (SHB-2). The field management strategies employed in this experiment were the same as those used in generally high-yielding fields. The specific operating procedures for the tillage treatments could view the supplementary document.

\subsection{Test items and methods}

In this study, through an ongoing field experiment involving long-term tillage and straw treatments, we measured the $\Delta^{13} \mathrm{C}$ of summer maize, soil water content (SWC), leaf area index (LAI), canopy microclimate, and $\mathrm{CO}_{2}$ concentration, and systematically studied the characteristics of $\Delta^{13} \mathrm{C}$ among the different summer maize layers and the relationships between $\Delta^{13} \mathrm{C}$ and the factors that influence it under different tillage methods.

\subsubsection{Soil water content}

Soil water content (SWC), which was measured at depths of 0-10, 10-20, 20-40, and 40-60 cm in the soil profile, was determined by drying method (Ma et al., 2021), with three replicates per treatment from the pre- 
105

106

107

108

109

110

111

112

113

114

115

116

117

118

119

120

121

122

123

124

filling and post-filling stages.

\subsubsection{Leaf area index}

LAI $\left(\mathrm{m}^{2} \mathrm{~m}^{-2}\right)$ was measured at the pre-filling and post-filling stages of summer maize, with three replicates per treatment. 3 maize plants were measured for per replicate. The leaf area of a single leaf is equal to the leaf length multiplied by the leaf width multiplied by the leaf coefficient (before flowing stage, unexpanded leaf coefficient is 0.5 , expanded leaf coefficient is 0.75 ; after flowing stage, leaf coefficient is 0.75 ) (Zhang et al., 2011). The LAI was determined by dividing the leaf area in square meters by the ground area in square meters.

\subsubsection{Collection and determination of gas samples}

Two maize plants with good growth, basic consistency, and no pest or disease, were covered with a chamber in each plot during the jointing stage. The chamber was designed as a cabinet surrounded by a transparent plastic sheet without covering top to connect to the atmosphere (Fig. 2), the volume was $2.88 \mathrm{~m}^{3}$ (1.2 $\mathrm{m}$ in length, 0.8 $\mathrm{m}$ in width, and $3 \mathrm{~m}$ in height). The bottom of this chamber was not sealed, embedded into the ground and the joints are sealed with soil. The gas sample was collected by an L-shaped polyvinyl (PVC) pipe from the chamber.

There were divided into three layers [upper layer (U, $240 \mathrm{~cm}$ above the ground), middle layer (M, $120 \mathrm{~cm}$ above the ground), and lower layer (L, $30 \mathrm{~cm}$ above the ground)] to collect the gas samples by a micro-vacuum pump, each sample was packed in $0.5 \mathrm{~L}$ gas sampling bag. Then, we took them back to the laboratory, using a Shimadzu gas chromatograph and a stable isotope mass spectrometer to measure the $\mathrm{CO} 2$ gas concentrations and $\delta^{13} \mathrm{C}$. The measurements were completed within 2 weeks.

\subsubsection{Canopy temperature and relative humidity}


125

126

The data was collected from 9:00 to 11:00 A.M., at the typical sunny day of the pre-filling and post-filling stages in summer maize. The canopy temperature and relative humidity distribution was measured in the three layers (The height of each layer was the same as the height of collecting the gas sample) by the portable meteorological monitor NK4000. Each layer was randomly repeated 5 times from the central row of the summer maize population.

\subsubsection{Collection and determination of plant samples}

Plant samples at L, M, and U were selected at the pre-filling and post-filling stages of summer maize. Plant samples were taken back to the laboratory, dried at $80{ }^{\circ} \mathrm{C}$, and ground. The $\delta{ }^{13} \mathrm{C}$ of the plants was measured using an isotope ratio mass spectrometer with a $0.1-0.2$. mg sample.

\subsubsection{Carbon-isotope analysis}

Natural ${ }^{13} \mathrm{C}$ abundance, expressed in $\delta$ units, can be calculated as follows:

$$
\delta^{13} \mathrm{C}(\%)=\left(\mathrm{R}_{\text {sample }} / \mathrm{R}_{\text {standard }}-1\right) \times 1000
$$

where $\mathrm{R}_{\text {sample }}$, the isotopic ratio of the study material, and $\mathrm{R}_{\text {standard }}$, the reference standard.

The source of plant photosynthesis is $\mathrm{CO}_{2}$, and isotopic discrimination values $(\Delta)$ can express isotopic effects.

Photosynthetic discrimination value can be described as follows:

$$
\Delta^{13} \mathrm{C}=\left(\delta^{13} \mathrm{C}_{\mathrm{a}}-\delta^{13} \mathrm{C}_{\mathrm{p}}\right) /\left(1+\delta^{13} \mathrm{C}_{\mathrm{p}} / 1000\right)
$$

where $\delta^{13} \mathrm{C}_{\mathrm{a}}$ is the $\delta^{13} \mathrm{C}$ of atmospheric $\mathrm{CO}_{2}$ and $\delta^{13} \mathrm{C}_{\mathrm{p}}$ is the $\delta^{13} \mathrm{C}$ of maize plants.

\subsubsection{Grain yield}

At harvest, yield was determined in three randomly selected regions of $10 \mathrm{~m} \times 2$ rows for each treatment, and each treatment was repeated with three times.

\subsection{Statistical analysis}


Duncan's multiple range test were used to perform multiple comparisons to calculated significant differences at

the 5\% level among mean value from various groups. Pearson method was used to determine the correlation

between difference factors. The test data were processed using Microsoft Excel 2016. Origin 8.0 was used for drawing.

151

\section{Results}

\subsection{Changes in the $\Delta^{13} \mathrm{C}$ of summer maize}

In both growing seasons, the $\Delta^{13} \mathrm{C}$ among the different summer maize layers was significantly influenced by both tillage methods and straw management (Table 1). Different straw management methods resulted in different $\Delta{ }^{13} \mathrm{C}$ values, and straw return significantly increased $\Delta^{13} \mathrm{C}$. Regardless of layer and growing seasons, the average $\Delta^{13} \mathrm{C}(5.21 \%)$ under straw return was significantly higher than that under straw removal (5.09\%). The results showed that the fluctuations in $\Delta^{13} \mathrm{C}$ in summer maize were consistent across the four tillage methods.

$\mathrm{SS}_{\mathrm{S}}$ significantly increased the $\Delta^{13} \mathrm{C}$. The $\Delta^{13} \mathrm{C}$ performance was ranked $\mathrm{SS}_{\mathrm{S}}>\mathrm{CT}_{\mathrm{S}}>\mathrm{RT}_{\mathrm{S}}>\mathrm{NT}_{\mathrm{S}}$, and there were significant differences in $\Delta^{13} \mathrm{C}$ under different tillage methods, which indicated that the tillage methods significantly affected the $\Delta^{13} \mathrm{C}$ of summer maize.

At different growth stages, the $\Delta^{13} \mathrm{C}$ among the different summer maize layers showed that the $\Delta^{13} \mathrm{C}$ at the pre-filling stage was higher than that at the post-filling stage. The lowest value of $\Delta^{13} \mathrm{C}$ was in $\mathrm{M}$, and the order of $\Delta^{13} \mathrm{C}$ among the different summer maize layers was $\mathrm{L}>\mathrm{U}>\mathrm{M}$.

\subsection{Analysis of the factors affecting the $\Delta^{13} \mathrm{C}$ of summer maize}

\subsubsection{Soil water content}

The SWC in the summer maize field decreased seasonally as the rainfall intensity decreased, and the trends 
167 168 169

170

171

172

173

174

175

176

177

178

179

180

181

182

183

184

for changes in SWC with time varied slightly between the two years of our study due to differences in the rainfall distributions between the two years (Fig. 1 and Fig. 3). The SWC at the pre-filling stage was higher than that at the post-filling stage. The SWC under the condition of straw return was higher than that under straw removal, which indicated that straw return enhanced soil water holding capacity, especially in the $0-10 \mathrm{~cm}$ soil layer. In the $0-10 \mathrm{~cm}$ soil layer, the two years' average $\mathrm{SWC}$ of $\mathrm{CT}_{\mathrm{S}}, \mathrm{SS}_{\mathrm{S}}, \mathrm{RT}_{\mathrm{S}}$, and $\mathrm{NT}_{\mathrm{S}}$ was increased by $4.82 \%, 5.68 \%$, $5.30 \%$, and $5.91 \%$, respectively, under straw return, compared with the straw removal treatments.

Across the soil depth range of 0-60 cm, SWC decreased initially and then increased with increasing soil depth.

In the $0-20 \mathrm{~cm}$ soil layer, the SWC was significantly lower under CTs than under the other treatments with straw return, and the SWC order was $\mathrm{RT}_{\mathrm{S}}>\mathrm{NT}_{\mathrm{S}}>\mathrm{SS}_{\mathrm{S}}>\mathrm{CT}_{\mathrm{S}}$. In the 20-40 cm soil layer, the $\mathrm{SWC}$ of $\mathrm{SS}_{\mathrm{S}}$ was significantly higher than that of the other treatments, and the SWC of $\mathrm{NT}_{\mathrm{S}}$ was the lowest among the different tillage treatments. In the 40-60 cm soil layer, the SWC performance ranking of the different tillage methods under straw return was $\mathrm{NT}_{\mathrm{S}}>\mathrm{SS}_{\mathrm{S}}>\mathrm{CT}_{\mathrm{S}}>\mathrm{RT}_{\mathrm{S}}$.

\subsubsection{Leaf area index}

The LAI of summer maize at the pre-filling stage was greater than that at the post-filling stage (Fig. 4). Overall, the LAI of the straw return treatment was greater than that of the straw removal treatment. At the pre-filling stage, LAI for $\mathrm{SS}_{\mathrm{S}}, \mathrm{RT}_{\mathrm{S}}$, and $\mathrm{NT}_{\mathrm{S}}$ were higher than those for $\mathrm{SS}_{0}, \mathrm{RT}_{0}$, and $\mathrm{NT}_{0}$, except for $\mathrm{CT}_{\mathrm{S}}$. Under straw return conditions, the order of the LAI of summer maize was $\mathrm{NT}_{\mathrm{S}}>\mathrm{SS}_{\mathrm{S}}>\mathrm{CT}_{\mathrm{S}}>\mathrm{RT}_{\mathrm{S}}$ at the pre-filling stage, and it was $\mathrm{SS}_{\mathrm{S}}>\mathrm{CT}_{\mathrm{S}}>\mathrm{RT}_{\mathrm{S}}>\mathrm{NT}_{\mathrm{S}}$ at the post-filling stage.

Under straw return conditions, the LAI of the $\mathrm{NT}_{\mathrm{S}}$ treatment was significantly higher than that of other treatments at the pre-filling stage. However, at the post-filling stage, the LAI of $\mathrm{NT}_{\mathrm{S}}$ treatment decreased and was the lowest among the tillage treatments. The average difference between the post-filling and pre-filling LAI 
for $\mathrm{CT}_{\mathrm{S}}, \mathrm{SS}_{\mathrm{S}}, \mathrm{RT}_{\mathrm{S}}$, and $\mathrm{NT}_{\mathrm{S}}$ was $0.72,0.73,0.75$, and 1.87 , respectively. Hence, the $\mathrm{LAI}$ of $\mathrm{NT}_{\mathrm{S}}$ decreased the most between pre-filling and post-filling, indicating that the leaf senescence rate under the $\mathrm{NT}_{\mathrm{S}}$ treatment was higher than those under the other three tillage methods.

\subsubsection{Air temperature in the summer maize canopy}

The changes in air temperature among the different summer maize layers at the pre-filling and the post-filling stages for summer maize in 2016 and 2017 are shown in Fig. 5. The air temperature decreased with the increase in height, and the air temperature at the pre-filling stage was significantly higher than that at the post-filling stage (both straw removal and straw return treatments). The air temperature under straw return was significantly higher than that under straw removal, which indicated that straw return significantly affected air temperature.

At the pre-filling stage, the air temperature of $\mathrm{CT}_{\mathrm{S}}$ was the highest in the lower layers of the summer maize canopy, whereas the highest temperature under $\mathrm{NT}_{\mathrm{S}}$ was observed in the upper layer. At the post-filling stage, the air temperature of $\mathrm{NT}_{\mathrm{S}}$ was highest among the three layers under straw removal in both two growing seasons, whereas $\mathrm{SS}_{\mathrm{S}}$ was lowest.

\subsubsection{Relative humidity in the summer maize canopy}

Straw return decreased relative humidity, and the relative humidity was higher at the pre-filling stage than at the post-filling stage (Fig. 6). Relative humidity was higher in the lower layer of the summer maize canopy than

it was in the middle and upper layers. The trends for the effects on relative humidity were similar among the different tillage methods and straw management conditions, with a high level of influence apparent in the lower layer.

At the pre-filling stage, the relative humidity under straw return was lower than that under straw removal. The results showed that the relative humidity of $\mathrm{NT}_{\mathrm{S}}$ treatment was significantly lower than those of the $\mathrm{CT}_{\mathrm{S}}, \mathrm{SS}_{\mathrm{S}}$, 
209

210

211

212

and $\mathrm{RT}_{\mathrm{S}}$ treatments in 2016 growing seasons under straw at the pre-filling stage. The average humidity in the

$\mathrm{CT}_{\mathrm{S}}, \mathrm{SS}_{\mathrm{S}}, \mathrm{RT}_{\mathrm{S}}$, and $\mathrm{ZT}_{\mathrm{S}}$ treatments was $49.96 \%, 48.16 \%, 48.28 \%$, and $47.13 \%$, respectively, which was $1.06 \%$, $5.36 \%, 2.41 \%$, and $1.67 \%$ lower, respectively, than that of average humidity under straw removal, indicating that straw return reduced soil water evaporative loss. Straw return and no-tillage treatments had high water retention, so the water dispersion under those treatments was lower during water shortages, and the relative humidity was low. In conclusion, the relative humidity of $\mathrm{CT}_{0}$ was the highest, and $\mathrm{NT}_{\mathrm{S}}$ was the lowest. Under the different tillage methods, straw return increased relative humidity in the summer maize canopy.

\subsection{Analysis of $\Delta{ }^{13} \mathrm{C}$ and its influencing factors}

SWC, LAI, air temperature, relative humidity, and the $\mathrm{CO}_{2}$ concentration can directly or indirectly affect the $\Delta^{13} \mathrm{C}$ of summer maize (Table 2). The results showed that the correlations of SWC, LAI, air temperature, relative humidity, and the $\mathrm{CO}_{2}$ concentration with $\Delta^{13} \mathrm{C}$ were significantly different among the different layers of summer maize. Among them, SWC, LAI, and air temperature were significantly positively correlated with the $\Delta^{13} \mathrm{C}$ in the lower layer, and, for SWC and LAI, this correlation was highly significant. By contrast, the relative humidity and the $\mathrm{CO}_{2}$ concentration had no significant correlation with $\Delta{ }^{13} \mathrm{C}$. In the middle layer, SWC, LAI, and air temperature significantly affected the $\Delta^{13} \mathrm{C}$ of summer maize, among which SWC and LAI with $\Delta^{13} \mathrm{C}$ had a very significant positive correlation. In the upper layer, the $\mathrm{CO}_{2}$ concentration and air temperature had significant positive correlations with $\Delta^{13} \mathrm{C}$, and SWC and LAI had an extremely significant positive correlation with $\Delta{ }^{13} \mathrm{C}$, whereas relative humidity had a very significant negative correlation with $\Delta{ }^{13} \mathrm{C}$. In addition, SWC and LAI were extremely significantly positively correlated with air temperature under the different summer maize layers, which indicated that the increases in SWC and LAI had a beneficial effect on the increase in air temperature, and they synergistically promoted or inhibited changes in air temperature, thereby affecting $\Delta^{13} \mathrm{C}$; SWC and LAI 
230

231

232

233

had an extremely significant positive correlation, and the larger the SWC was, the larger the LAI was, indicating that water availability significantly affected the LAI of summer maize plants and promoted the growth of summer maize plants under good soil moisture conditions, thereby increasing the LAI. There was a significant positive correlation between the $\mathrm{CO}_{2}$ concentration and LAI in the lower layer, and an extremely significant negative correlation between the $\mathrm{CO}_{2}$ concentration and relative humidity.

According to the correlation coefficient, the rankings for the factors affecting the $\Delta^{13} \mathrm{C}$ of summer maize canopy in the lower, middle, and upper layers was LAI $>\mathrm{SWC}>$ air temperature $>\mathrm{CO}_{2}$ concentration $>$ relative humidity, LAI $>$ SWC $>$ air temperature $>$ relative humidity $>\mathrm{CO}_{2}$ concentration, and LAI $>$ SWC $>$ relative humidity $>$ air temperature $>\mathrm{CO}_{2}$ concentration, respectively. Under the different summer maize layers, various factors have different contributions to $\Delta^{13} \mathrm{C}$. SWC, LAI, and air temperature were significantly or extremely significantly correlated with the $\Delta^{13} \mathrm{C}$ in $\mathrm{L}, \mathrm{M}$, and $\mathrm{U}$, all of which were the main factors affecting $\Delta^{13} \mathrm{C}$, and the $\mathrm{CO}_{2}$ concentration played an important role in $\Delta^{13} \mathrm{C}$ in $\mathrm{U}$. Interestingly, we found that there was a negative correlation between relative humidity and $\Delta{ }^{13} \mathrm{C}$ at different canopy heights in summer maize, among which, in $\mathrm{U}$, relative humidity and $\Delta^{13} \mathrm{C}$ had a significant negative correlation.

\subsection{The relationship between the $\Delta^{13} \mathrm{C}$ of summer maize and yield}

The results of the correlation analysis for summer maize $\Delta^{13} \mathrm{C}$ and yield under both straw removal and straw return treatments is shown in Fig. 7. It can be seen that the $\Delta^{13} \mathrm{C}$ of summer maize at the pre-filling stage showed a significant positive correlation with the summer maize yield. The $\Delta^{13} \mathrm{C}$ of summer maize in the middle of the canopy had a very significant positive correlation with the summer maize yield, with a significance level reaching 0.0001 . However, there was no significant correlation between $\Delta^{13} \mathrm{C}$ and yield at the post-filling stage in summer maize. 


\section{4. Discussion}

\section{4.1. The $\Delta^{13} \mathrm{C}$ at different layers in the summer maize canopy}

Temperature, moisture, and the atmospheric $\mathrm{CO}_{2}$ concentration all affect the plant leaf $\Delta^{13} \mathrm{C}$ value ( $\mathrm{Li}$ et al.,

2017). Under different tillage systems, $\Delta{ }^{13} \mathrm{C}$ at the pre-filling stage was greater than that at the post-filling stage,

and the plants fractionated heavy isotopes more vigorously at the pre-filling stage, that is, their ability to

and the accompanying waning of the photosynthetic assimilation capacities of the summer maize plants. The

$\Delta^{13} \mathrm{C}$ values were significantly different among the different summer maize layers. The lowest value of $\Delta{ }^{13} \mathrm{C}$

was found in the middle of the summer maize canopy, whereas the highest $\Delta^{13} \mathrm{C}$ was in the lower maize canopy.

The $\Delta{ }^{13} \mathrm{C}$ order among the different summer maize layers was $\mathrm{L}>\mathrm{U}>\mathrm{M}$. There may be two main reasons: soil

respiration emits large quantities of $\mathrm{CO}_{2}$ to the atmosphere, resulting in a lower $\delta^{13} \mathrm{C}$ near the ground atmosphere.

Liu et al. (2019c) suggested that the contribution of summer maize field soil emissions to photosynthesis is

$20.37 \%-29.03 \%$. As the canopy height increases, the ratio of the $\mathrm{CO}_{2}$ released from the soil to atmospheric $\mathrm{CO}_{2}$

gradually declines. To a certain extent, increasing soil carbon emissions can increase the rate of maize

photosynthesis. Plant photosynthetic carbon assimilation is discriminatory, and its reaction matrix is mainly

${ }^{12} \mathrm{CO}_{2}$. Similarly, if respiration releases more $\mathrm{CO}_{2}$, predominantly containing ${ }^{12} \mathrm{C}$, the $\delta^{13} \mathrm{C}$ of soil $\mathrm{CO}_{2}$ will be

lower than that of the plant canopy; that is, the $\Delta^{13} \mathrm{C}$ will be greater in the lower layer than in the middle layer,

as it was in our study. Secondly, due to photosynthesis, the canopy took the lead in assimilating ${ }^{12} \mathrm{CO}_{2}$, which 
272

274

275

276

277

278

279

280

281

282

283

284

285

286

287 closer to the forest surface, the more obvious the isotope depletion of plant leaves.

In the summer maize growing season, the $\Delta^{13} \mathrm{C}$ values of $\mathrm{SS}_{\mathrm{S}}, \mathrm{CT}_{\mathrm{S}}$, and $\mathrm{RT}_{\mathrm{S}}$ were significantly higher than that of $\mathrm{NT}_{\mathrm{S}}$. The main reasons may be as follows: first, the degree of soil disturbance under $\mathrm{SS}_{\mathrm{S}}, \mathrm{CT}_{\mathrm{S}}$, and $\mathrm{RT}_{\mathrm{S}}$ was higher than that under $\mathrm{NT}_{\mathrm{S}}$. During the summer maize growing season, the temperature was higher, the rainfall was frequent, so the soil temperature and soil moisture were also high, which provided the theoretical conditions for soil respiration. Soil respiration releases a large amount of $\mathrm{CO}_{2}$. Second, tillage improves soil permeability, enhances the migration and diffusion of gases in the soil, promotes the decomposition of organic matter, and increases the release of $\mathrm{CO}_{2}$ from soil respiration. Compared with the other tillage methods, $\mathrm{NT}_{\mathrm{S}}$ effectively reduced soil disturbance and the chance of soil-air contact, reduced the decomposition of soil organic matter, and significantly reduced soil respiration, which was consistent with previous research results (Six et al., 2004; Yonemura et al., 2014). Different straw management conditions resulted in different $\Delta^{13} \mathrm{C}$ values. In the two periods, the $\Delta^{13} \mathrm{C}$ of the straw return treatment was significantly higher than that of the straw removal treatment. The main reasons may be as follows: firstly, the plant straw that was returned to the soil is a carbon source, and the straw was decomposed into various organic and inorganic substances, providing many nutrients for plant growth and releasing $\mathrm{CO}_{2}$ (Negassa et al., 2015; Song et al., 2017); secondly, straw return improved the physical and chemical properties of soil, maintained soil structure and fertility (Jones et al., 2005), promoted the growth and extension of plant roots, and promoted the growth of the aboveground plant parts, increased the LAI, and improved photosynthesis. The increase in photosynthesis increased the capture of $\mathrm{CO}_{2}$, and finally affected the $\Delta^{13} \mathrm{C}$. The lower $\Delta^{13} \mathrm{C}$ for summer maize may reduce lower photosynthesis resulted lower yield. And Wei et al. (2019) found that the more ${ }^{13} \mathrm{C}$-photosynthate distribution to ears, and the less ${ }^{13} \mathrm{C}$-photosynthate distribution to stems could achieve a greater yield consequently. In future studies, we will investigate whether

PeerJ reviewing PDF | (2021:06:63005:2:0:NEW 9 Jan 2022) 
293

294

295

296

297

298

299

300

301

302

303

304

305

306

307

308

309

310

311

312

313

the decrease of $\Delta^{13} \mathrm{C}$ reduced photosynthesis for summer maize.

\subsection{Influencing factors of $\Delta^{13} \mathrm{C}$}

Among the five factors (i.e., SWC, LAI, air temperature, relative humidity, and $\mathrm{CO}_{2}$ concentration) that affect

the $\Delta^{13} \mathrm{C}$ of the summer maize canopy, there was variation in the effects of these factors at different heights

within the maize canopy, and the relative contribution of each factor to $\Delta^{13} \mathrm{C}$ differed. From the correlation

analysis of these various factors to $\Delta^{13} \mathrm{C}$, it can be seen that SWC, LAI, and air temperature were the important

factors affecting $\Delta^{13} \mathrm{C}$ in the lower, middle, and upper layers. However, there was only a weak correlation

between relative humidity and the $\Delta^{13} \mathrm{C}$ in $\mathrm{U}$, which may be related to the influence of air flow and solar radiation

in the upper level of the summer maize canopy. Studies have shown that temperature has a negative correlation

with plant $\delta^{13} \mathrm{C}$ (Morecroft et al., 1990). The results of this experiment demonstrated that temperature was significantly positively correlated with plant $\Delta^{13} \mathrm{C}$. Plant growth was largely affected by water availability. There

have been many studies on the relationship between water availability or precipitation and the composition of plant $\Delta^{13} \mathrm{C}$. For example, Tambussi (2007) reported that $\Delta^{13} \mathrm{C}$ can be used to predict the WUE of $\mathrm{C}_{3}$ plants.

Badeck (2005) found that different crops or crop organs have different isotopic compositions. The $\Delta^{13} \mathrm{C}$ values

of different plant organs indicate that their WUE varies. In short, $\Delta^{13} \mathrm{C}$ can indirectly indicate crop yield and

WUE (Khan et al., 2007; Chen et al., 2011; Gresset et al., 2014). SWC and LAI have important effects on air temperature, and SWC, LAI, and air temperature are all very significantly related, indicating that there is some interaction between the three, and mutual adjustment affects the canopy $\Delta^{13} \mathrm{C}$. When SWC decreases, crop physiological indicators, including air temperature and stomatal conductance, will first show some characteristics of change. Most of the water absorbed by crops is lost through leaf transpiration to maintain a

balanced leaf temperature. If the soil moisture is insufficient, and the evapotranspiration intensity in the air is

Peer] reviewing PDF | (2021:06:63005:2:0:NEW 9 Jan 2022) 
314 very large, it will cause the leaf transpiration to decrease and the leaf surface temperature to increase. Webber

315 (2016) showed in their study that the air temperature is related to the SWC, and the influence of SWC on crop

316 air temperature in that study was more obvious.

317 5. The $\Delta^{13} \mathrm{C}$ of summer maize is comprehensively controlled by many factors such as SWC, LAI, air

temperature, relative humidity, and other factors. Under different field conditions, the contribution of each factor

to $\Delta^{13} \mathrm{C}$ is different, and the combined effects of multiple factors may have a complex interaction with $\Delta^{13} \mathrm{C}$.

Further studies are required to clearly define the quantitative relationship between factor interactions for a deeper study of the characteristics of $\Delta^{13} \mathrm{C}$.

\section{Conclusions}

Subsoiling and straw return significantly increased the $\Delta^{13} \mathrm{C}$ of summer maize, and the $\Delta^{13} \mathrm{C}$ in the middle

layer was the smallest among the three layers. The $\Delta^{13} \mathrm{C}$ of each summer maize layer had a consistent positive

correlation with SWC, LAI, and air temperature, and there was a significant positive correlation between the

$\Delta{ }^{13} \mathrm{C}$ in the middle layer (pre-filling stage) and yield. Therefore, carbon isotopes can be used to evaluate summer

maize yield, and subsoiling can be used as a reasonable tillage practice to improve summer maize grain yield in the NCP.

\section{$329 \quad$ Competing financial interests}

The authors declare no competing financial interests.

\section{Acknowledgements}

This work was financially supported by the National Nature Science Foundation of China (grant numbers 
335

336

337

338

reviewers who had provided much help to improve this paper.

\section{References}

Badeck, F.W., Tcherkez, G., Salvador, Nogués, Clément, Piel, Ghashghaie, J., 2005. Post-photosynthetic fractionation of stable carbon isotopes between plant organs — a widespread phenomenon. Rapid Commun. Mass Spectrom. 19, 1381-1391.

Balwinder-Singh, Humphreys, E., Eberbach, P.L., Katupitiya, A., Yadvinder-Singh, Kukal, S.S., 2011. Growth, yield and water productivity of zero till wheat as affected by rice straw mulch and irrigation schedule. Field Crops Res. 121, 209-225.

Bissett, A., Richardson, A.E., Baker, G., Kirkegaard, J., Thrall, P.H., 2013. Bacterial community response to tillage and nutrient additions in a long-term wheat cropping experiment. Soil Biol. Biochem. 58, 281-292.

Chen, J., Chang, S.X., Anyia, A.O., 2011. The physiology and stability of leaf carbon isotope discrimination as a measure of water-use efficiency in Barley on the Canadian Prairies. J. Agro. Crop Sci. 197, 1-11.

Cui, N.B., Du, T.S., Kang, S.Z., Li, F.S., Hu, X.T., Wang, M.X., Li, Z.J., 2009. Relationship between stable carbon isotope discrimination and water use efficiency under regulated deficit irrigation of pear-jujube tree. Agr. Water Manage. 96, 1615-1622.

Damesin, C., Lelarge, C., 2003. Carbon isotope composition of current-year shoots from Fagus sylvatica in relation to growth, respiration and use of reserves. Plant Cell Environ. 26, 207-219.

Gresset, S., Rademacher, S., Ouzunova, M., Ouzunova, T., Schön, C.C., Westhoff, P., Westermeier, P., 2014. Stable carbon isotope discrimination is under genetic control in the $\mathrm{C}_{4}$ species maize with several genomic regions influencing trait expression. Plant Physiol. 164, 131-143.

Jennings, T.N., Smith, J.E., Cromack, K., Sulzman, E.W., McKay, D., Caldwell, B.A., Beldin, S.I., 2012. Impact of postfire logging on soil bacterial and fungal communities and soil biogeochemistry in a mixed-conifer forest in central Oregon. Plant Soil. 350 , 393-411. 
355

356

357

358

359

360

361

362

363

364

365

366

367

368

369

370

371

372

373

374

Jones, C., McConnell, C., Coleman, K., Cox, P., Falloon, P., Jenkinson, D., Powlson, D., 2005. Global climate change and soil carbon stocks; predictions from two contrasting models for the turnover of organic carbon in soil. Global. Change. Biol. 11, 154-

166.

Khan, H.R., Link, W., Hocking, T., Stoddard, F., 2007. Evaluation of physiological traits for improving drought tolerance in faba bean (Vicia faba L.). Plant Soil. 292, 205-217.

Kristiansen, S.M., Hansen, E.M., Jensen, L.S., Christensen, B.T., 2005. Natural ${ }^{13} \mathrm{C}$ abundance and carbon storage in Danish soils under continuous silage maize. Eur. J. Agron. 22, 107-117.

Latifmanesh, H., Deng, A., Nawaz, M.M., Li, L., Chen, Z.J., Zheng, Y.T., Wang, P., Song, Z.W., Zhang, J., Zheng, C.Y., Zhang, W.J., 2018. Integrative impacts of rotational tillage on wheat yield and dry matter accumulation under corn-wheat cropping system. Soil Till. Res. 184,100-108.

Li, M.X., Peng, C.H., Wang, M., Yang, Y.Z., Zhang, K.R., Li, P., Yang, Y., Ni, J., Zhu, Q., 2017. Spatial patterns of leaf $\delta^{13} \mathrm{C}$ and its relationship with plant functional groups and environmental factors in China. J. Geophys. Res-Biogeo. 122, $1564-1575$.

Liu, Z., Gao, T.P., Liu, W.T., Sun, K., Xin, Y.N., Liu, H.G., Wang, S.Z., Li, G., Han, H.F., Li, Z.J., Ning, T.Y., 2019a. Effects of part and whole straw returning on soil carbon sequestration in $\mathrm{C}_{3}-\mathrm{C}_{4}$ rotation cropland. J. Plant Nutr. Soil Sc. 182(3), 429-440.

Liu, Z., Ma, F.Y., Hu, T.X., Zhao, K.G., Gao, T.P., Zhao, H.X., Ning, T.Y., 2019b. Using stable isotopes to quantify water uptake from different soil layers and water use efficiency of wheat under long-term tillage and straw return practices. Agr. Water Manage. 229, 105933.

Liu, Z., Liu, W.T., Liu, H.T., Gao, T.P., Zhao, H.X., Li, G., Han, H.F., Li, Z.J., Rattan, L., Ning, T.Y., 2019c. Capture of soil respiration for higher photosynthesis with lower $\mathrm{CO}_{2}$ emission. J. Clean. Prod. 246, 119029.

Ma, Y.Z., Zhang, H., Xue, Y.F., Gao, Y.B., Qian, X., Dai, H.C., Liu, K.C., Li, Q.Q., Li, Z.X., 2021. Effect of sulfur fertilizer on 
375

376

377

378

379

380

381

382

383

384

385

386

387 summer maize grain yield and soil water utilization under different irrigation patterns from anthesis to maturity. Agr. Water

Manage. 250, 106828 .

Morecroft, M.D., Woodward, F.I., 1990. Experimental Investigations on the Environmental Determination of $\delta^{13} \mathrm{C}$ at Different

Altitudes. J. Exp. Bot. 231, 1303-1308.

Negassa, W, Price, R.F., Basir, A., Snapp, S.S., Kravchenko, A., 2015. Cover crop and tillage systems effect on soil $\mathrm{CO}_{2}$ and $\mathrm{N}_{2} \mathrm{O}$ fluxes in contrasting topographic positions. Soil Till. Res. 154, 64-74.

Shao,Y.H., Xie, Y.X., Wang, C.Y., Yue, J.Q., Yao, Y.Q., Li, X.D., Liu, W.X., Zhu, Y.J., Guo, T.C., 2016. Effects of different soil conservation tillage approaches on soilnutrients, water use and wheat-maize yield in rainfed dry-landregions of North China.

Eur. J. Agron. 81, 37-45.

Silveira, L.D., Sternberg, L., Mulkey, S.S., Wright, S.J., 1989. Ecological interpretation of leaf carbon isotope ratios:influence of respired carbon dioxide. Ecology. 70, 1317-1324.

Six, J., Ogle, S.M., Breidt, F.J., Conant, R.T., Mosier, A.R., Paustian, K., 2004. The potential to mitigate global warming with notillage management is only realized when practised in the long term. Global Change Biol. 10, 155-160.

Song, G., Novotny, E.H., Mao, J.D., Hayes, M.H.B., 2017. Characterization of transformations of maize residues into soil organic matter. Sci. Total Environ. 579, 1843-1854.

Tambussi, E.A., Bort, J., Araus, J.L., 2007. Water use efficiency in $\mathrm{C}_{3}$ cereals under Mediterranean conditions: a review of physiological aspects. Ann. Appl. Biol. 150, 307-321.Tharayil, N., Suseela,V., Triebwasser, D.J., Preston, C.M., Gerard, P.D, Dukes, J.S., 2011. Changes in the structural composition and reactively of Acer rubrum leaf litter tannins exposed to warming and altered precipitation: Climatic stress induced tannins are more reactive. New Phytol. 191, 132-145.

Peer] reviewing PDF | (2021:06:63005:2:0:NEW 9 Jan 2022) 
395

396

397

398

399

400

401

402

403

404

405

406

407

408

409

410

spatial econometric perspective based on China's province-level data. J. Clean. Prod. 204, 96-106.

Webber, H., Ewert, F., Kimball, B.A., Siebert, S., White, J.W., Wall, G.W., Ottman, M.J., Trawally, D.N.A., Gaiser, T., 2016. Simulating canopy temperature for modelling heat stress in cereals. Environ. Modell. Softw. 77, 143-155.

Wei, S., Wang, X., Li, G., Jiang, D., Dong, S., 2019. Maize Canopy Apparent Photosynthesis and (13)C-Photosynthate Reallocation in Response to Different Density and N Rate Combinations. Front Plant Sci 10, 1113.

Xu J., Han H.F., Ning T.Y., Li, Z.J., Lal, R., 2019. Long-term effects of tillage and straw management on soil organic carbon, crop yield, and yield stability in a wheat-maize system. Field Crops Res. 233, 33-40.

Xue, L.Z., Khana, S., Sun, Min., Anwarc, S., Ren, A.X., Gao, Z.Q., Lin, W., Xue, J.F., Yang, Z.P., Deng, Y., 2019. Effects of tillage practices on water consumption and grain yield of dryland winter wheat under different precipitation distribution in the loess plateau of China. Soil Till. Res. 191, 66-74.

Yonemura, S., Nouchi, I., Nishimura, S., Sakurai, G., Togami, K., Yagi, K., 2014. Soil respiration, $\mathrm{N}_{2} \mathrm{O}$, and $\mathrm{CH}_{4} \mathrm{emissions} \mathrm{from}$ an Andisol under conventional-tillage and notillage cultivation for 4 years. Biol. Fert. Soils. 50, 63-74.

Zhang, C.C., Li, X.Y., Wu, H.W., Wang, P., Wang, Y., Wu, X.C., Li, W., Huang, Y.M., 2017. Reaumuria soongorica and Nitraria sphaerocarpa: Isotopic approaches with physiological evidence. Plant Soil. 419, 169-187.

Zhang, Y.Q., Yang, H.S., Gao, J.L., Zhang, R.F., Wang, Z.G., Xu, S.J., Fan, X.Y., Yang, S.H., 2011. Study on canopy structure and physiological characteristics of super-high yield spring maize. Sci. Agr. Sinica. 44, 4367-4376

Peer) reviewing PDF | (2021:06:63005:2:0:NEW 9 Jan 2022) 
Figure 1

The daily precipitation and mean temperature at the trial site

Note: Climate change during the maize growing period from 2016 to 2017 in the experiment.

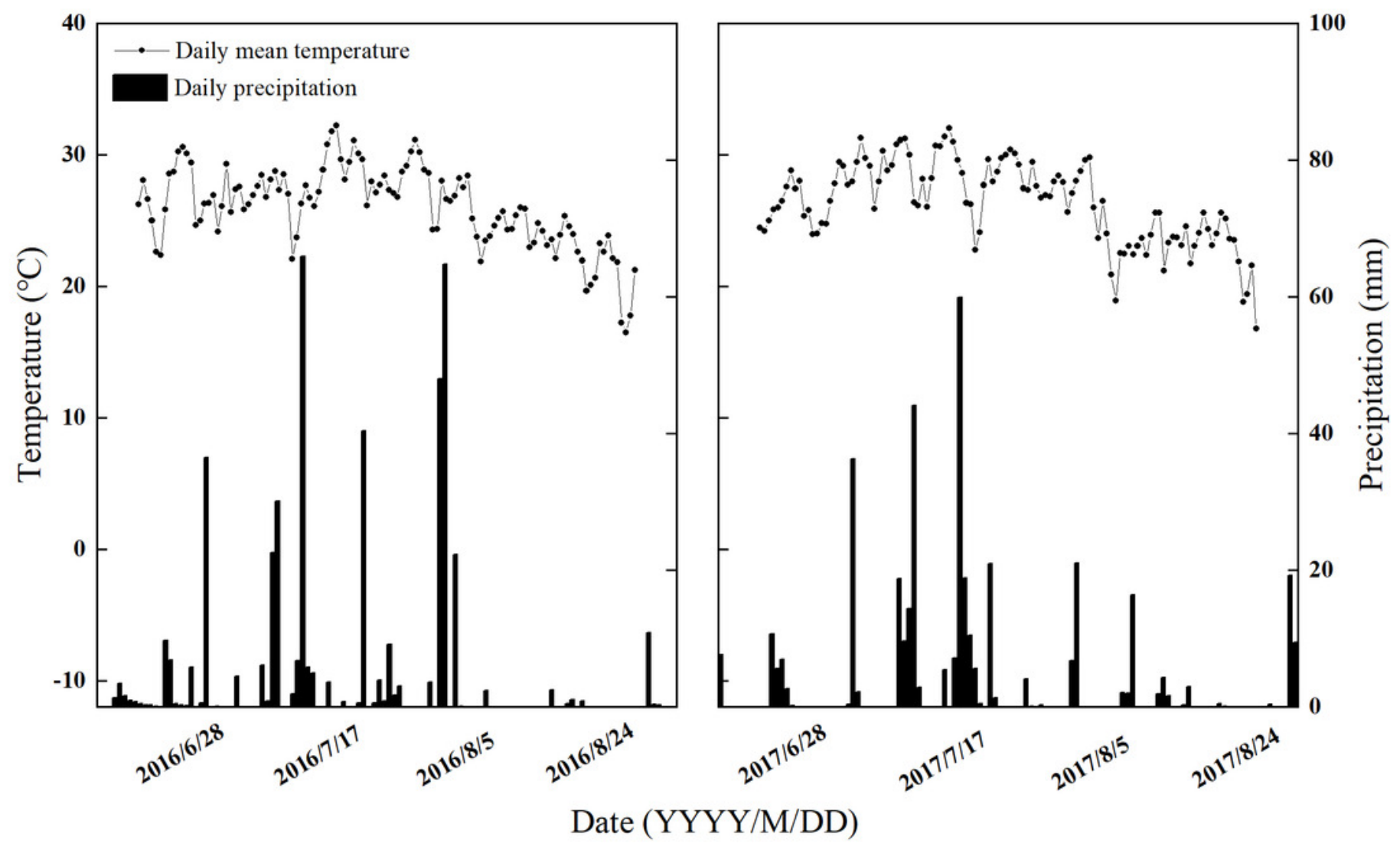


Figure 2

Simulation test device of microzone

Note: 1- Iron hoop; 2-Top opening indication; 3- $4 \mathrm{~cm}$ square tube at side length; 4- PVC film; 5- Fixing screw; 6- Screw hole; 7- Maize; 8- Door; 9- Fixed screw on pedestal; 10- Iron plate; 11- $5 \mathrm{~cm}$ square tube at side length;12- Iron wire; 13- Band spring. L (deeper layer, $30 \mathrm{~cm}$ above the ground), $M$ (middle layer, $150 \mathrm{~cm}$ above the ground), and $U$ (upper layer, $240 \mathrm{~cm}$ above the ground).

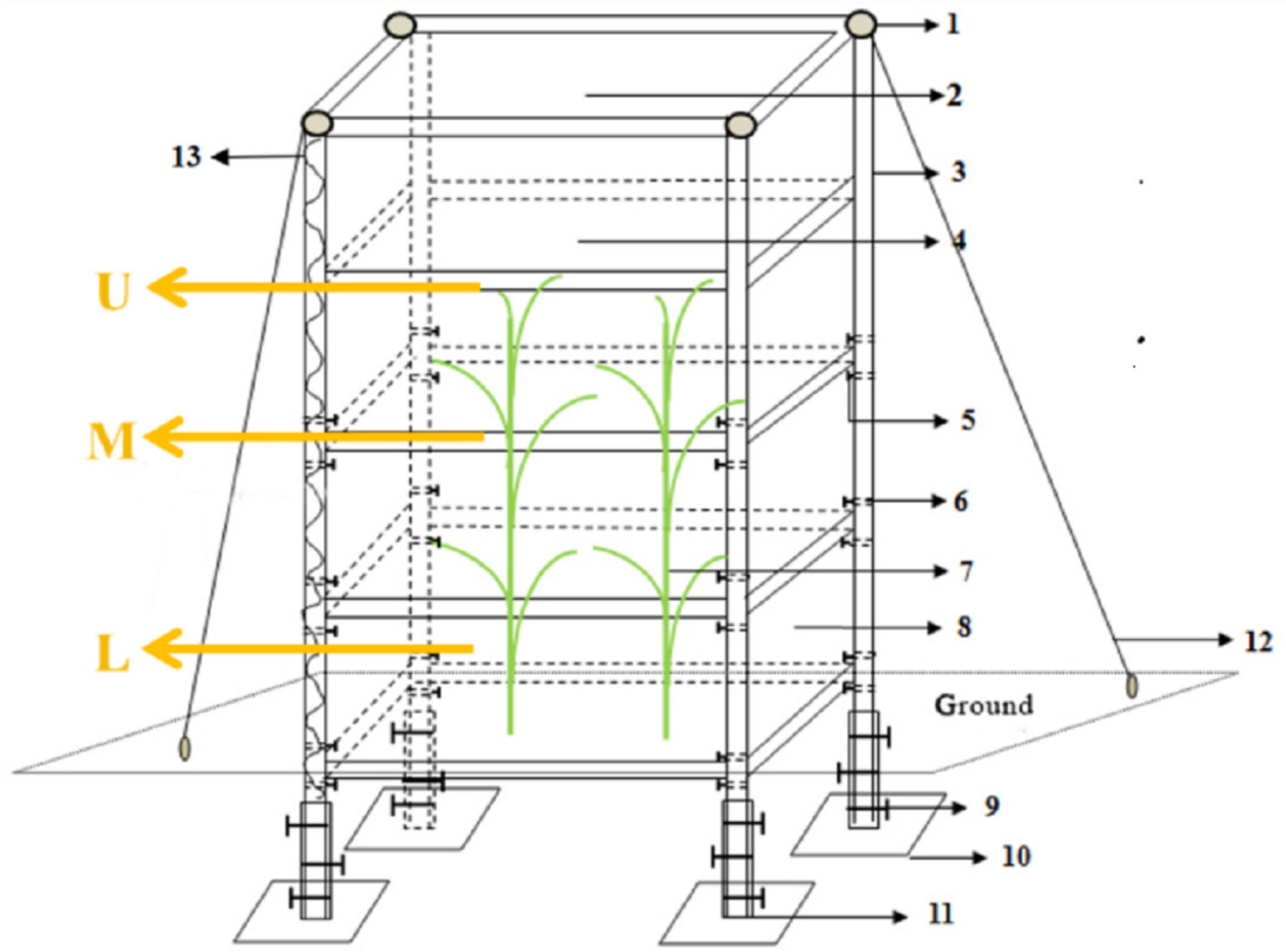


Figure 3

Effects of tillage methods on soil water content

a1 (straw removal at the pre-filling), a2 (straw return at the pre-filling), b1 (straw removal at the post-filling), b2 (straw return at the post-filling). $\mathrm{CT}_{0}$ (conventional tillage with straw removal), $\mathrm{SS}_{0}$ (subsoiling with straw removal), $\mathrm{RT}_{0}$ (rotary tillage with straw removal), $\mathrm{NT}_{0}$ (no-tillage with straw removal), $\mathrm{CT}_{\mathrm{S}}$ (conventional tillage with straw return), $\mathrm{SS}_{\mathrm{s}}$ (subsoiling with straw return), $\mathrm{RT}_{\mathrm{s}}$ (rotary tillage with straw return) and $\mathrm{NT}_{\mathrm{s}}$ (no-tillage with straw return). Horizontal bars are standard errors. *indicates significant differences at the 0.05 levels.

Soil water content $(\%)$
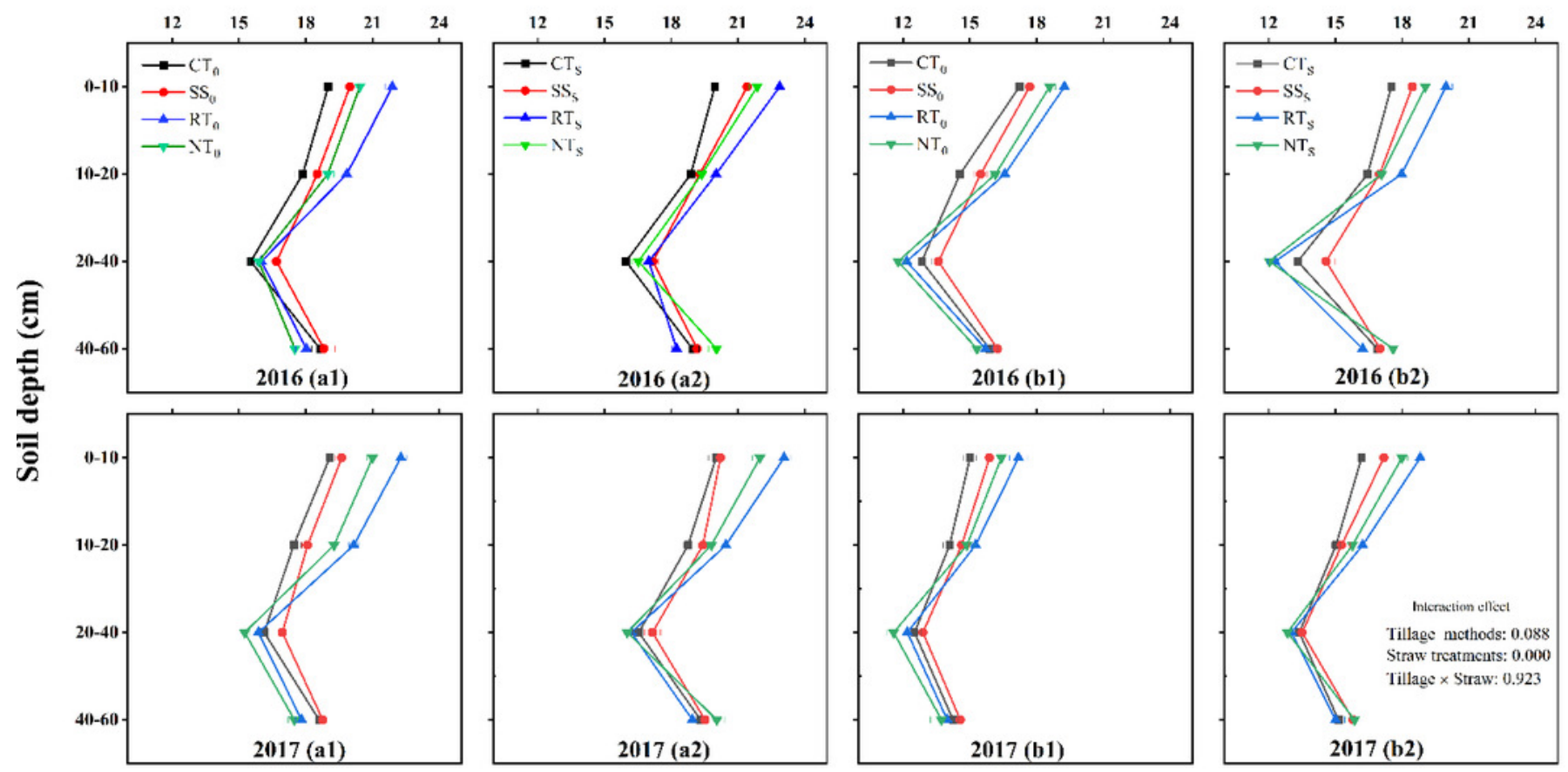


\section{Figure 4}

Leaf area index at the pre-filling and the post-filling

a1 (straw removal at the pre-filling), a2 (straw return at the pre-filling), b1 (straw removal at the post-filling), b2 (straw return at the post-filling). $\mathrm{CT}_{0}$ (conventional tillage with straw removal), $\mathrm{SS}_{0}$ (subsoiling with straw removal), $\mathrm{RT}_{0}$ (rotary tillage with straw removal), $\mathrm{NT}_{0}$ (no-tillage with straw removal), $\mathrm{CT}_{\mathrm{s}}$ (conventional tillage with straw return), $\mathrm{SS}_{\mathrm{s}}$ (subsoiling with straw return), $\mathrm{RT}_{s}$ (rotary tillage with straw return) and $\mathrm{NT}_{s}$ (no-tillage with straw return). Different letters in each column indicate significant differences between different treatments $(P<0.05$; Duncan's test). The graphs in upper and lower panel represent data from 2016 and 2017 respectively. 

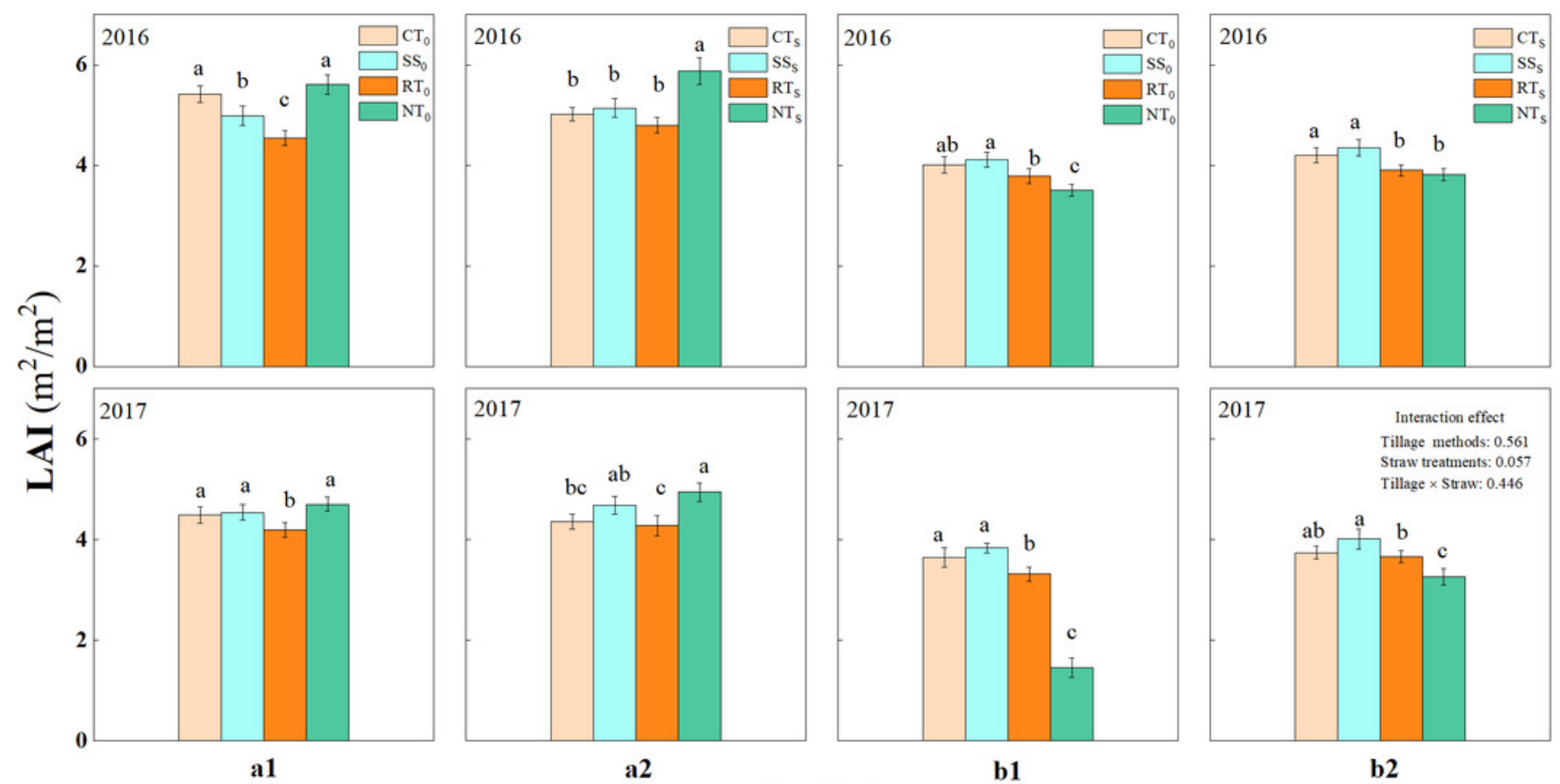

b1

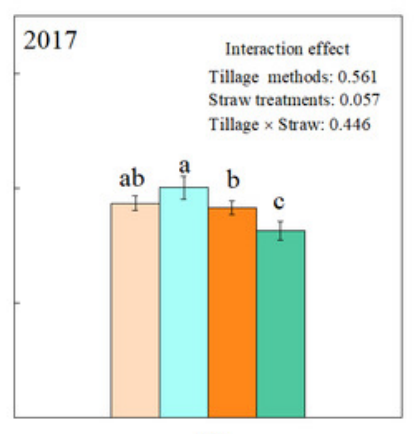

Period

b2 


\section{Figure 5}

Vertical distribution of air temperature in summer maize canopy

a1 (straw removal at the pre-filling), a2 (straw return at the pre-filling), b1 (straw removal at the post-filling), b2 (straw return at the post-filling). $\mathrm{CT}_{0}$ (conventional tillage with straw removal), $\mathrm{SS}_{0}$ (subsoiling with straw removal), $\mathrm{RT}_{0}$ (rotary tillage with straw removal), $\mathrm{NT}_{0}$ (no-tillage with straw removal), $\mathrm{CT}_{\mathrm{s}}$ (conventional tillage with straw return), $\mathrm{SS}_{\mathrm{s}}$ (subsoiling with straw return), $\mathrm{RT}_{s}$ (rotary tillage with straw return) and $\mathrm{NT}_{s}$ (no-tillage with straw return). EFS (early filling stage) and LFS (last filling stage). L (lower layer, $30 \mathrm{~cm}$ above the ground), $M$ (middle layer, $150 \mathrm{~cm}$ above the ground), and $U$ (upper layer, $240 \mathrm{~cm}$ above the ground). Different letters in each column indicate significant differences between different treatments $(P<0.05 ;$ Duncan's test). 

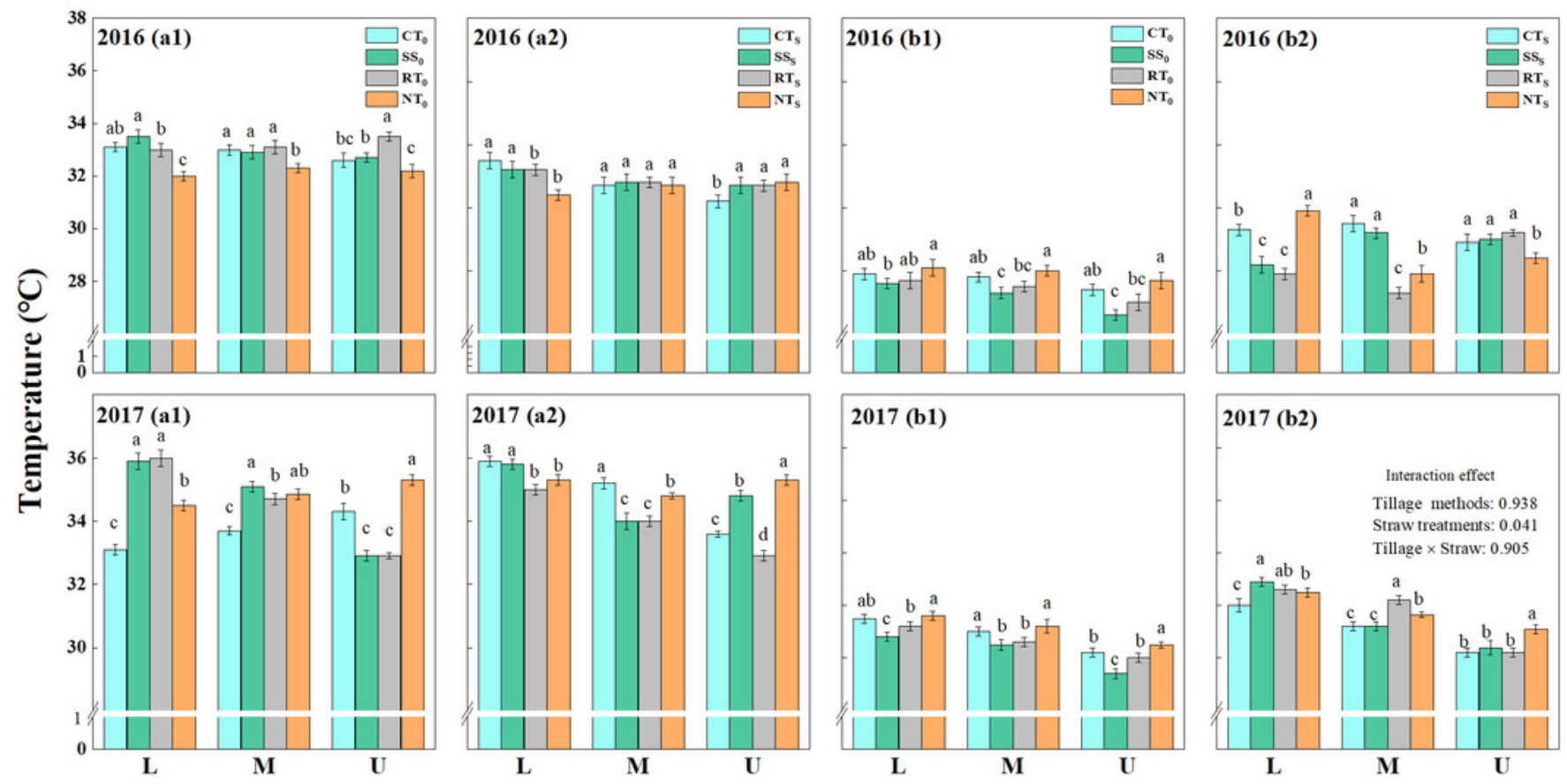

Layer 


\section{Figure 6}

Vertical distribution of relative humidity in summer maize canopy

a1 (straw removal at the pre-filling), a2 (straw return at the pre-filling), b1 (straw removal at the post-filling), b2 (straw return at the post-filling). $\mathrm{CT}_{0}$ (conventional tillage with straw removal), $\mathrm{SS}_{0}$ (subsoiling with straw removal), $\mathrm{RT}_{0}$ (rotary tillage with straw removal), $\mathrm{NT}_{0}$ (no-tillage with straw removal), $\mathrm{CT}_{\mathrm{s}}$ (conventional tillage with straw return), $\mathrm{SS}_{\mathrm{s}}$ (subsoiling with straw return), $\mathrm{RT}_{s}$ (rotary tillage with straw return) and $\mathrm{NT}_{s}$ (no-tillage with straw return). EFS (early filling stage) and LFS (last filling stage). L (lower layer, $30 \mathrm{~cm}$ above the ground), $M$ (middle layer, $150 \mathrm{~cm}$ above the ground), and $U$ (upper layer, $240 \mathrm{~cm}$ above the ground). Different letters in each column indicate significant differences between different treatments $(P<0.05 ;$ Duncan's test). 

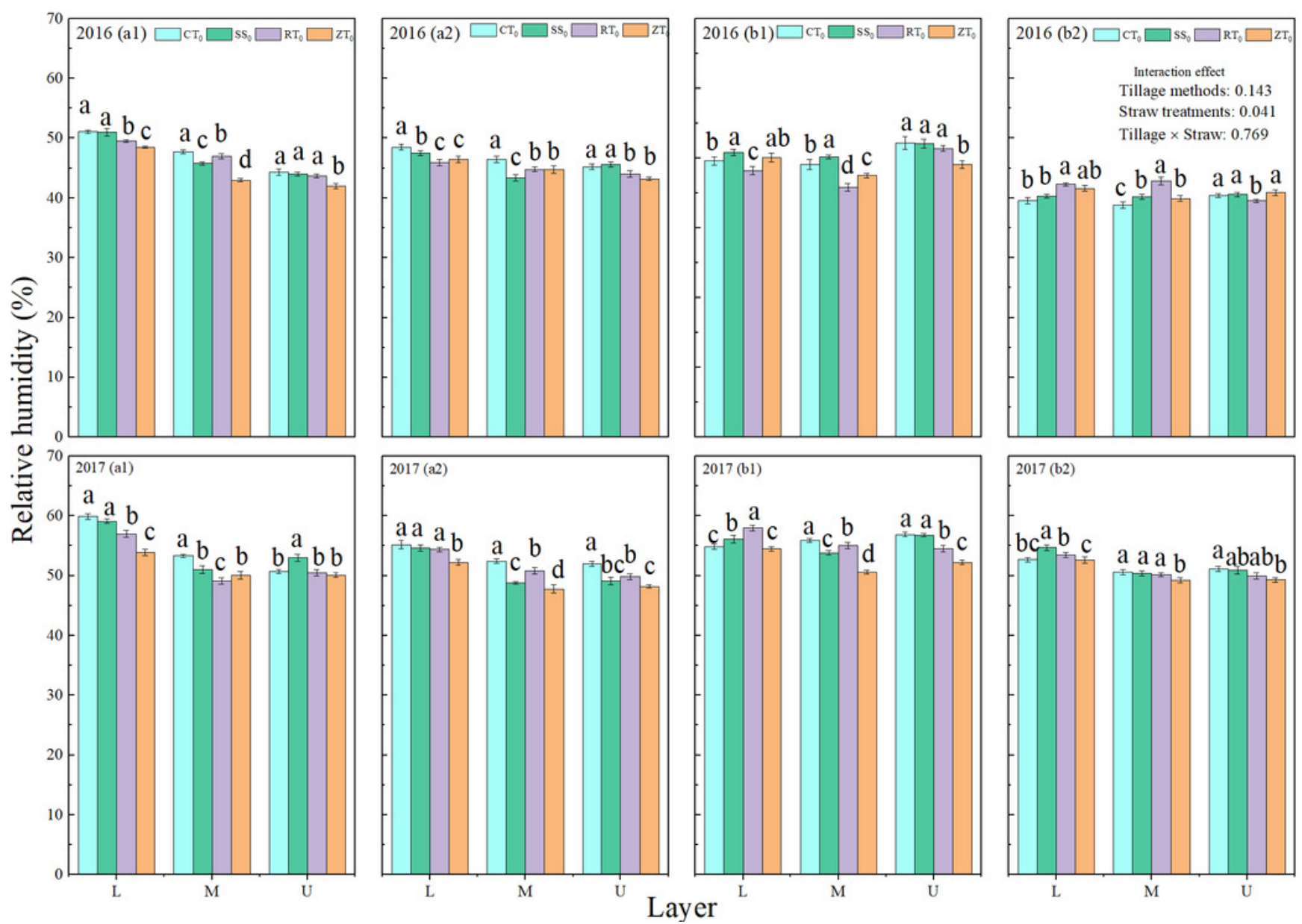
Figure 7

The relationship between the $\Delta 13 \mathrm{C}$ of summer maize and yield

a1 ( $L$ at the pre-filling), a2 ( $M$ at the pre-filling), a3 ( $U$ at the pre-filling), b1 ( $L$ at the postfilling), b2 ( $M$ at the post-filling), b3 ( $U$ at the post-filling). " $t / h^{22}$ " means tonnes/hectare.
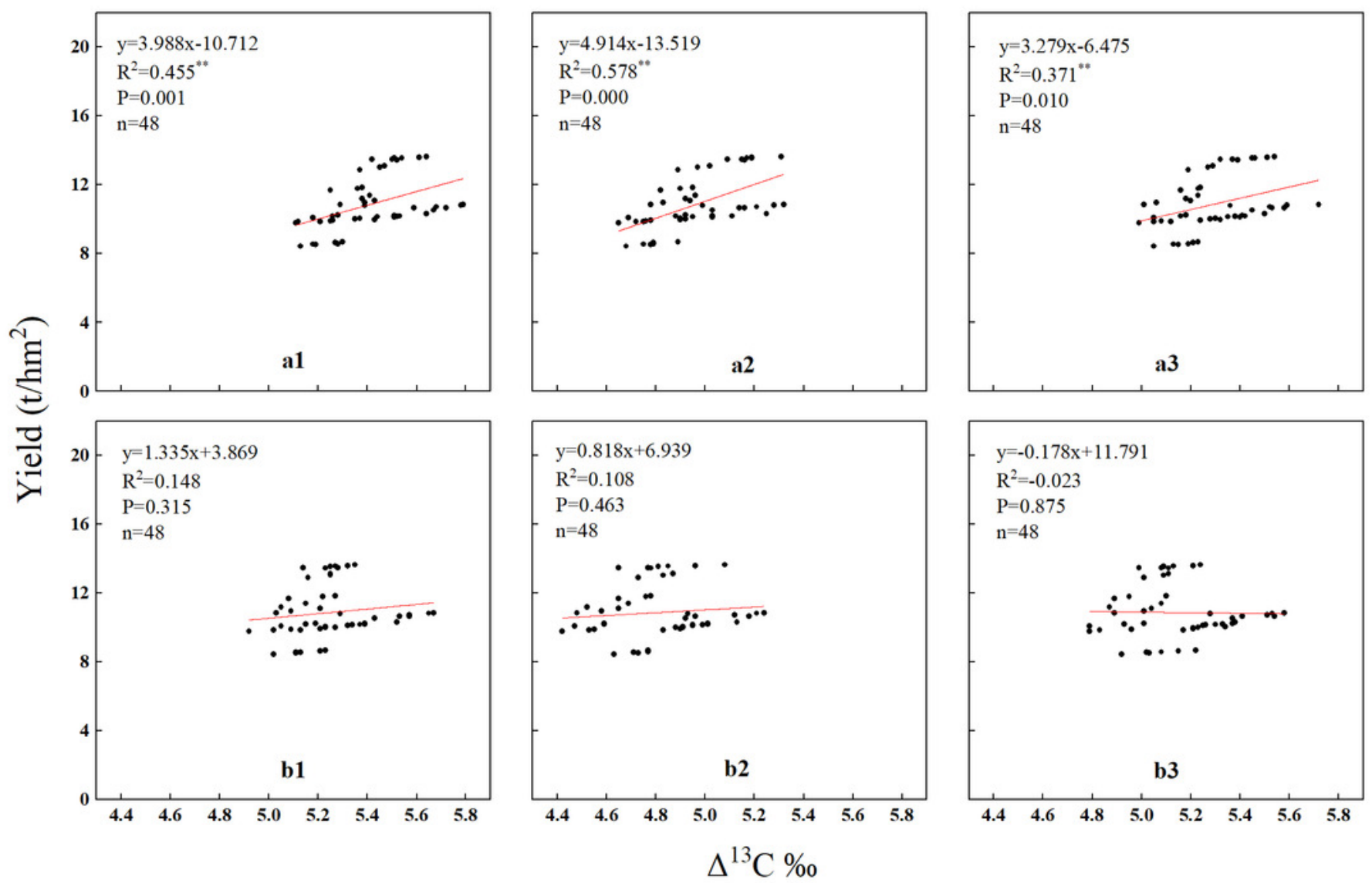


\section{Table $\mathbf{1}$ (on next page)}

Vertical distribution of the $\Delta^{13} \mathrm{C}$ in summer maize canopy at pre-filling and post-filling under different treatments

$\mathrm{CT}_{0}$ (conventional tillage with straw removal), $\mathrm{SS}_{0}$ (subsoiling with straw removal), $\mathrm{RT}_{0}$ (rotary tillage with straw removal), $\mathrm{NT}_{0}$ (no-tillage with straw removal), $\mathrm{CT}_{\mathrm{s}}$ (conventional tillage with straw return), $\mathrm{SS}_{\mathrm{S}}$ (subsoiling with straw return), $\mathrm{RT}_{\mathrm{S}}$ (rotary tillage with straw return) and $\mathrm{NT}_{\mathrm{S}}$ (no-tillage with straw return). L (lower layer, $30 \mathrm{~cm}$ above the ground), M (middle layer, 150 $\mathrm{cm}$ above the ground), and $\mathrm{U}$ (upper layer, $240 \mathrm{~cm}$ above the ground). Different letters in each column indicate significant differences between different treatments $(P<0.05$; Duncan's test). 


\begin{tabular}{|c|c|c|c|c|c|c|c|c|c|c|c|c|}
\hline \multirow{2}{*}{ Treatments } & \multicolumn{3}{|c|}{ Pre-filling (\%) } & \multicolumn{3}{|c|}{ Post-filling (\%) } & \multicolumn{3}{|c|}{ Pre-filling (\%o) } & \multicolumn{3}{|c|}{ Post-filling(\%o) } \\
\hline & $\mathrm{L}$ & M & $\mathrm{U}$ & $\mathrm{L}$ & M & $\mathrm{U}$ & $\mathrm{L}$ & M & $\mathrm{U}$ & $\mathrm{L}$ & M & $\mathrm{U}$ \\
\hline & 2016 & & & & & & 2017 & & & & & \\
\hline \multicolumn{13}{|l|}{ Straw } \\
\hline 0 & $5.40 \pm 0.19 \mathrm{a}$ & $4.91 \pm 0.16 \mathrm{a}$ & $5.31 \pm 0.17 \mathrm{a}$ & $5.28 \pm 0.18 \mathrm{a}$ & $4.90 \pm 0.14 \mathrm{a}$ & $5.24 \pm 0.18 \mathrm{a}$ & $5.29 \pm 0.12 b$ & $4.85 \pm 0.12 b$ & $5.16 \pm 0.10 \mathrm{~b}$ & $5.14 \pm 0.11 \mathrm{a}$ & $4.65 \pm 0.15 \mathrm{a}$ & $4.96 \pm 0.11 \mathrm{~b}$ \\
\hline $\mathrm{S}$ & $5.50 \pm 0.20 \mathrm{a}$ & $5.05 \pm 0.19 \mathrm{a}$ & $5.40 \pm 0.17 \mathrm{a}$ & $5.39 \pm 0.18 \mathrm{a}$ & $4.97 \pm 0.18 \mathrm{a}$ & $5.32 \pm 0.16 \mathrm{a}$ & $5.47 \pm 0.10 \mathrm{a}$ & $5.06 \pm 0.17 \mathrm{a}$ & $5.31 \pm 0.17 \mathrm{a}$ & $5.20 \pm 0.10 \mathrm{a}$ & $4.74 \pm 0.18 \mathrm{a}$ & $5.06 \pm 0.11 \mathrm{a}$ \\
\hline \multicolumn{13}{|l|}{ Tillage } \\
\hline $\mathrm{CT}$ & $5.51 \pm 0.08 \mathrm{~b}$ & $5.05 \pm 0.12 b$ & $5.40 \pm 0.06 \mathrm{~b}$ & $5.37 \pm 0.10 \mathrm{~b}$ & $5.00 \pm 0.07 \mathrm{~b}$ & $5.30 \pm 0.07 \mathrm{~b}$ & $5.41 \pm 0.11 \mathrm{ab}$ & $5.02 \pm 0.15 \mathrm{a}$ & $5.31 \pm 0.12 \mathrm{ab}$ & $5.21 \pm 0.08 \mathrm{ab}$ & $4.75 \pm 0.08 b$ & $5.03 \pm 0.10 \mathrm{ab}$ \\
\hline SS & $5.71 \pm 0.08 \mathrm{a}$ & $5.19 \pm 0.10 \mathrm{a}$ & $5.57 \pm 0.09 \mathrm{a}$ & $5.57 \pm 0.09 \mathrm{a}$ & $5.11 \pm 0.13 \mathrm{a}$ & $5.49 \pm 0.08 \mathrm{a}$ & $5.51 \pm 0.10 \mathrm{a}$ & $5.09 \pm 0.16 \mathrm{a}$ & $5.37 \pm 0.14 \mathrm{a}$ & $5.26 \pm 0.07 \mathrm{a}$ & $4.88 \pm 0.13 \mathrm{a}$ & $5.13 \pm 0.08 \mathrm{a}$ \\
\hline RT & $5.35 \pm 0.11 \mathrm{c}$ & $4.89 \pm 0.12 \mathrm{c}$ & $5.28 \pm 0.09 \mathrm{c}$ & $5.25 \pm 0.08 \mathrm{c}$ & $4.90 \pm 0.04 b$ & $5.26 \pm 0.06 b$ & $5.34 \pm 0.12 b$ & $4.92 \pm 0.15 \mathrm{ab}$ & $5.20 \pm 0.10 b c$ & $5.15 \pm 0.09 b c$ & $4.61 \pm 0.11 \mathrm{c}$ & $4.96 \pm 0.12 \mathrm{~b}$ \\
\hline NT & $5.23 \pm 0.07 \mathrm{~d}$ & $4.78 \pm 0.07 \mathrm{c}$ & $5.16 \pm 0.07 \mathrm{~d}$ & $5.14 \pm 0.08 \mathrm{~d}$ & $4.73 \pm 0.06 \mathrm{c}$ & $5.07 \pm 0.11 \mathrm{c}$ & $5.27 \pm 0.13 b$ & $4.79 \pm 0.10 \mathrm{~b}$ & $5.07 \pm 0.07 \mathrm{c}$ & $5.06 \pm 0.10 \mathrm{c}$ & $4.54 \pm 0.08 \mathrm{c}$ & $4.92 \pm 0.10 \mathrm{~b}$ \\
\hline \multicolumn{13}{|l|}{ Coupling } \\
\hline $\mathrm{CT}_{0}$ & $5.46 \pm 0.04 \mathrm{~cd}$ & $4.96 \pm 0.07 \mathrm{c}$ & $5.36 \pm 0.05 \mathrm{c}$ & $5.32 \pm 0.08 \mathrm{c}$ & $4.97 \pm 0.05 b c$ & $5.28 \pm 0.08 \mathrm{c}$ & $5.33 \pm 0.07 \mathrm{~cd}$ & $4.89 \pm 0.07 \mathrm{~cd}$ & $5.21 \pm 0.04 b c$ & $5.19 \pm 0.10 \mathrm{ab}$ & $4.73 \pm 0.07 \mathrm{bc}$ & $4.98 \pm 0.11 \mathrm{bc}$ \\
\hline $\mathrm{SS}_{0}$ & $5.66 \pm 0.07 \mathrm{ab}$ & $5.11 \pm 0.07 \mathrm{~b}$ & $5.52 \pm 0.07 \mathrm{ab}$ & $5.51 \pm 0.07 \mathrm{~b}$ & $5.02 \pm 0.14 b$ & $5.44 \pm 0.09 \mathrm{ab}$ & $5.43 \pm 0.05 b c$ & $4.96 \pm 0.07 \mathrm{~cd}$ & $5.25 \pm 0.05 b$ & $5.22 \pm 0.05 \mathrm{ab}$ & $4.81 \pm 0.07 \mathrm{ab}$ & $5.07 \pm 0.05 \mathrm{ab}$ \\
\hline $\mathrm{RT}_{0}$ & $5.28 \pm 0.08 \mathrm{e}$ & $4.80 \pm 0.09 \mathrm{~d}$ & $5.22 \pm 0.09 \mathrm{de}$ & $5.19 \pm 0.05 \mathrm{de}$ & $4.88 \pm 0.04 c$ & $5.24 \pm 0.09 \mathrm{~cd}$ & $5.24 \pm 0.05 \mathrm{de}$ & $4.83 \pm 0.12 \mathrm{de}$ & $5.13 \pm 0.07 \mathrm{bcd}$ & $5.13 \pm 0.07 b c$ & $4.55 \pm 0.07 \mathrm{~cd}$ & $4.91 \pm 0.11 \mathrm{bc}$ \\
\hline $\mathrm{NT}_{0}$ & $5.20 \pm 0.08 \mathrm{e}$ & $4.75 \pm 0.06 \mathrm{~d}$ & $5.13 \pm 0.07 \mathrm{e}$ & $5.08 \pm 0.05 \mathrm{e}$ & $4.71 \pm 0.07 \mathrm{~d}$ & $5.01 \pm 0.08 \mathrm{e}$ & $5.16 \pm 0.08 \mathrm{e}$ & $4.72 \pm 0.06 \mathrm{e}$ & $5.04 \pm 0.05 \mathrm{~d}$ & $5.01 \pm 0.09 \mathrm{c}$ & $4.50 \pm 0.07 \mathrm{~d}$ & $4.86 \pm 0.09 \mathrm{c}$ \\
\hline $\mathrm{CT}_{\mathrm{S}}$ & $5.56 \pm 0.07 b c$ & $5.13 \pm 0.11 \mathrm{~b}$ & $5.44 \pm 0.05 \mathrm{bc}$ & $5.41 \pm 0.10 \mathrm{bc}$ & $5.03 \pm 0.09 b$ & $5.32 \pm 0.07 \mathrm{bc}$ & $5.49 \pm 0.06 \mathrm{ab}$ & $5.15 \pm 0.05 \mathrm{ab}$ & $5.41 \pm 0.08 \mathrm{a}$ & $5.22 \pm 0.07 \mathrm{ab}$ & $4.77 \pm 0.11 \mathrm{ab}$ & $5.07 \pm 0.07 \mathrm{ab}$ \\
\hline $\mathrm{SS}_{\mathrm{S}}$ & $5.75 \pm 0.06 \mathrm{a}$ & $5.27 \pm 0.06 \mathrm{a}$ & $5.61 \pm 0.10 \mathrm{a}$ & $5.63 \pm 0.05 \mathrm{a}$ & $5.19 \pm 0.06 \mathrm{a}$ & $5.54 \pm 0.04 \mathrm{a}$ & $5.59 \pm 0.06 \mathrm{a}$ & $5.22 \pm 0.08 \mathrm{a}$ & $5.48 \pm 0.08 \mathrm{a}$ & $5.30 \pm 0.06 \mathrm{a}$ & $4.94 \pm 0.15 \mathrm{a}$ & $5.19 \pm 0.07 \mathrm{a}$ \\
\hline $\mathrm{RT}_{\mathrm{S}}$ & $5.42 \pm 0.09 \mathrm{~d}$ & $4.98 \pm 0.06 \mathrm{c}$ & $5.34 \pm 0.05 \mathrm{~cd}$ & $5.31 \pm 0.05 \mathrm{~cd}$ & $4.92 \pm 0.04 b c$ & $5.27 \pm 0.04 \mathrm{c}$ & $5.43 \pm 0.06 \mathrm{bc}$ & $5.01 \pm 0.12 b c$ & $5.26 \pm 0.10 \mathrm{~b}$ & $5.16 \pm 0.12 \mathrm{abc}$ & $4.66 \pm 0.13 \mathrm{bcd}$ & $5.01 \pm 0.12 b c$ \\
\hline $\mathrm{NT}_{\mathrm{S}}$ & $5.25 \pm 0.06 \mathrm{e}$ & $4.81 \pm 0.07 \mathrm{~d}$ & $5.19 \pm 0.05 \mathrm{e}$ & $5.19 \pm 0.05 \mathrm{de}$ & $4.75 \pm 0.03 \mathrm{~d}$ & $5.13 \pm 0.10 \mathrm{de}$ & $5.37 \pm 0.07 \mathrm{bc}$ & $4.85 \pm 0.08 \mathrm{de}$ & $5.09 \pm 0.10 \mathrm{~cd}$ & $5.11 \pm 0.09 b c$ & $4.57 \pm 0.09 \mathrm{~cd}$ & $4.98 \pm 0.08 \mathrm{bc}$ \\
\hline \multicolumn{13}{|l|}{ Interaction } \\
\hline Straw 秸秆 & 0.004 & 0.000 & 0.007 & 0.001 & 0.021 & 0.033 & 0.000 & 0.000 & 0.000 & 0.096 & 0.045 & 0.011 \\
\hline Tillage & 0.000 & 0.000 & 0.000 & 0.000 & 0.000 & 0.000 & 0.000 & 0.000 & 0.000 & 0.005 & 0.000 & 0.006 \\
\hline $\begin{array}{l}\text { Straw } \times \text { Tillag } \\
\mathrm{e}\end{array}$ & 0.741 & 0.500 & 0.899 & 0.977 & 0.396 & 0.683 & 0.885 & 0.491 & 0.193 & 0.843 & 0.859 & 0.990 \\
\hline
\end{tabular}

1 


\section{Table 2 (on next page)}

Correlation coefficients of $\Delta^{13} \mathrm{C}$ and its affecting factors under different treatments

$\mathrm{L}$ (lower layer, $30 \mathrm{~cm}$ above the ground), $\mathrm{M}$ (middle layer, $150 \mathrm{~cm}$ above the ground), and $\mathrm{U}$ (upper layer, $240 \mathrm{~cm}$ above the ground). SWC60, LAI, T and M represented soil water content at 0-60 $\mathrm{cm}$ soil layer, leaf area index for summer maize, air temperature in the summer maize canopy, and relative humidity in the summer maize canopy. ${ }^{*}=$ significance $(P<$ $0.05) ; * *=$ significance $(\mathrm{P}<0.01)$. 
1

\begin{tabular}{|c|c|c|c|c|c|c|c|}
\hline Layer & Parameter & $\Delta^{13} \mathrm{C}$ & $\mathrm{SWC}_{60}$ & LAI & $\mathrm{T}$ & M & $\mathrm{CO}_{2}$ \\
\hline \multirow{5}{*}{$\mathrm{L}$} & $\mathrm{SWC}_{60}$ & $0.547 * *$ & 1 & & & & \\
\hline & LAI & $0.577 * *$ & $0.759^{* *}$ & 1 & & & \\
\hline & $\mathrm{T}$ & $0.449^{*}$ & $0.871^{* *}$ & $0.552 * *$ & 1 & & \\
\hline & M & -0.108 & 0.125 & -0.062 & $0.393 *$ & 1 & \\
\hline & $\mathrm{CO}_{2}$ & 0.261 & 0.271 & $0.430^{*}$ & -0.062 & $-0.719 * *$ & 1 \\
\hline \multirow{5}{*}{$\mathrm{M}$} & $\mathrm{SWC}_{60}$ & $0.513 * *$ & 1 & & & & \\
\hline & LAI & $0.554^{* *}$ & $0.759^{* *}$ & 1 & & & \\
\hline & $\mathrm{T}$ & $0.437^{*}$ & $0.895^{* *}$ & $0.631 * *$ & 1 & & \\
\hline & M & -0.282 & -0.039 & -0.186 & 0.137 & 1 & \\
\hline & $\mathrm{CO}_{2}$ & 0.247 & 0.127 & 0.327 & -0.143 & $-0.829 * *$ & 1 \\
\hline \multirow{5}{*}{$\mathrm{U}$} & $\mathrm{SWC}_{60}$ & $0.522 * *$ & 1 & & & & \\
\hline & LAI & $0.582 * *$ & $0.759^{* *}$ & 1 & & & \\
\hline & $\mathrm{T}$ & $0.423^{*}$ & $0.907^{* *}$ & $0.670 * *$ & 1 & & \\
\hline & M & $-0.440^{*}$ & -0.193 & -0.308 & -0.140 & 1 & \\
\hline & $\mathrm{CO}_{2}$ & $0.390^{*}$ & 0.150 & 0.339 & 0.021 & $-0.850^{* *}$ & 1 \\
\hline
\end{tabular}

2 